\title{
Efficacy of Organic Products as Black Pepper Foliar Fertilizer
}

\author{
Yap Chin Ann \\ Research and Development Division, Malaysian Pepper Board, Lot 1115 JalanUtama, Pending Industrial Area, 93916 Kuching, \\ Sarawak, Malaysia
}

Tel: 6082-331811; Fax: 682-336877

\begin{abstract}
Black pepper (Piper nigrum), known as "King of spices", is a perennial export oriented cash crop in Malaysia. To furnish the pepper berries according to the world demand, integrated fertilizersregimes in black pepper is becoming relevant today. An investigation was conducted to determinethe influence of newly developed foliar fertilizer when used in combination with soil NPK fertilizeron different growth parameters of the black pepper cultivar SemongokAman. The plants were applied with different rate of NPK compound fertilizer (N:12\%, P:12\%, K:17\%: Mg:2\%) and foliar fertilizer.The plants were allowed to grow for upto12 months of age for taking observations on differentvegetative growth parameters. Considering the realization of highest response for five important growth parameters viz., plant height $(59.30 \mathrm{~cm})$, plant dry weight $(99.68 \mathrm{~g})$, plant root length $(74.92 \mathrm{~cm})$, dried black pepper yield (572.52 g) and relative growth rate, $R G R\left(1.65 \mathrm{~g} \mathrm{~g}^{-1} \mathrm{day}^{-1}\right)$ after 12 months of planting, it may be concluded that the application of foliar fertilizer supplementation at $5 \mathrm{ml} / \mathrm{L}$ of water along with $50 \%$ of soil NPK fertilizer may be the best nutrient schedule under this agro-climatic condition.
\end{abstract}

Keywords-Black pepper, foliar fertilizer, NPK fertilizer, nutrient uptake, vegetative growth.

\section{INTRODUCTION}

Pepper of commerce is produced from the fruit of the perennial climbing vine Piper nigrum $L$. It is the most important of all spice crops and has been regarded as the King of Spices. Pepper has been extensive culinary uses and is most widely used as a condiment. It is an important component of many ground spice formulae which are used for food seasoning. Besides, pepper has also been used in many ways today, unlike in the past. Other than food, it finds application in the preparation of traditional and modern medicines, nutraceuticals, perfumes, and other products. Also pepper is used in many differentforms;some of the value added products that have been developed include pepper oil, pepper oleoresin, green pepper brine and etc. With the development of modern science and technologies and greater awareness and demand among people for the use of natural products, particularly in food and pharmaceuticals, pepper has indeed secured a better position and has a better prospect in the years to come. Pepper now ranks as the second most important foreign exchange earner for Sarawak, after palm oil, with over 70,000 farm families dependent on the crop for their cash incomes. Currently, the production and quality of pepper berries are facing serious problems because there is scarcity of pepper cutting to replace the ageing and non-productive pepper stock plant in the field. This replacement is becoming difficult due to the cumbersome procedure of raising 5 noted cutting in the field and nursery stages, and the continued decline in soil fertility.

To furnish the pepper berries according to the world demand, farmers are insistently using physical and chemical approaches to sustain the soil fertility and pepper production. Recently, organic approaches are favorable in enhancing the growth and productivity of black pepper plants[2, 3]. Looking into this perspective the farmers has to look for an alternative measures to sustain his farming business profitability. The utilization of seaweed and fish emulsion based liquid fertilizer are one of the prime inputs to stimulate plant growth as it has been well knowns as plant growth regulator containing various type of phytohormone and nutrient. For example seaweed product are best known for their auxin and cytokinin contents, as these endogenous hormone are responsible for cell division and root and shoot elongation, respectively [4]. Additionally, this organic input also contains salicyclic acids that play a vital role in plant response to abiotic stress [5].

The development of foliar fertilizer is not intended to replace the soil fertilization. The supplies of major nutrient (nitrogen, phosphorus, and potassium) were still fully dependent on the uses of soil application. This is because 
this technique is far more effective and economical than through foliar application. However, many study had proven that the application of foliar fertilizer able to enhance the growth of spice crops through supplying secondary nutrients (calcium, magnesium, sulfur) and micronutrients (zinc, manganese, iron, copper, boron, and molybdenum) and supplementing N-P-K needs for short and/or critical growth stage periods. Besides that, the foliar fertilizer has also been reported manage to delay natural senescence processes of crops at reproductive growth stages [6].

In order to achieve optimal nutrient management for perennial cropping system, black pepper required a management package in which a number of nutrient management measures need to used together to keep overall yield losses to a minimum and for sustainable crop production. Such integrated management programmes are now used for some pest and diseases and experience has shown that to be successful. Therefore, the present study was undertaken to evaluate the efficacy of newly developed seaweed based foliar fertilizer when used in combination of soil NPK fertilizer enable to sustain the vegetative growth of black pepper under greenhouse condition.

\section{MATERIAL AND METHODS}

Phytohormone and free amino acids analysis fortested foliar fertilizer was performed prior conducting the experiment. The assay tested showed that this foliar fertilizer contains 5type of phytohormone that can stimulate the plant growth viz: Abscisic acid (ABA), Jasmonic acid (J),Salicylic acid (SA), Indole-3-acetic acid (IAA) hormoneand 20 type of free amino acid (Fig. 1).The summaries of nutrient content in foliar fertilizer are shown in Table 1. The foliar fertilizer was applied with a motorized sprayer at monthly intervals up to a maximum of 12 applications. Application was done early in the morning.

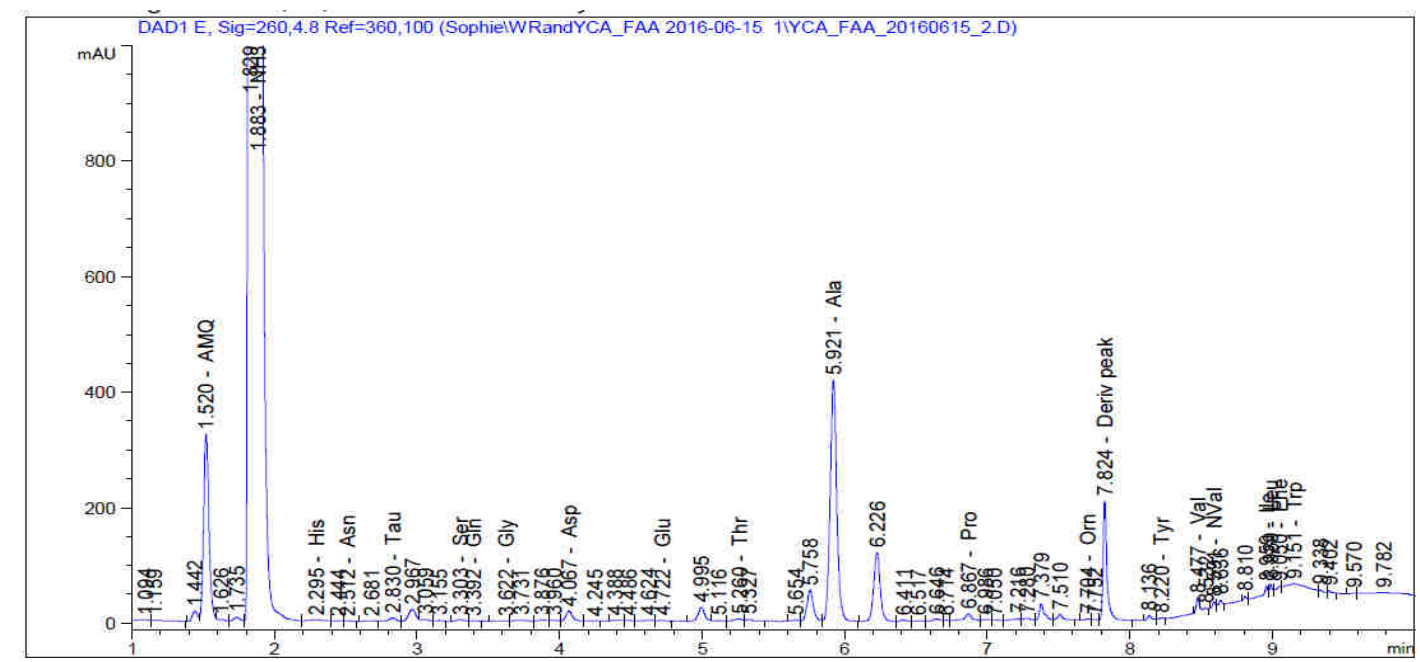

Fig. 1: LCMS Chromatogram of free amino acids

Table 1: Nutrient content of newly developed foliar fertilizer

\begin{tabular}{llll}
\hline Nitrogen & $1.20 \%$ & Manganese & $7.3 \mathrm{ppm}$ \\
\hline Phosphorus & $0.35 \%$ & Iron & $250 \mathrm{ppm}$ \\
\hline Potassium & $4.20 \%$ & Zinc & $30 \mathrm{ppm}$ \\
\hline Magnesium & $0.84 \%$ & Copper & $7.2 \mathrm{ppm}$ \\
\hline Calcium & $1.40 \%$ & Abscisic acid & $0.062 \mathrm{pmol} / \mu \mathrm{L}$ \\
\hline Sulphur & $1.3 \%$ & Jasmonic acid & $0.013 \mathrm{pmol} / \mu \mathrm{L}$ \\
\hline Boron & $140 \mathrm{ppm}$ & Salicylic acid & $5.273 \mathrm{pmol} / \mu \mathrm{L}$ \\
\hline Cobalt & $8.2 \mathrm{ppm}$ & Indole-3-acetic acid & $4.453 \mathrm{pmol} / \mu \mathrm{L}$ \\
\hline Molybdenum & $0.14 \mathrm{ppm}$ & Cytokinin & $3.251 \mathrm{pmol} / \mu \mathrm{L}$ \\
\hline
\end{tabular}

The trial was conducted during 2015 at Malaysian Pepper Board nursery, Kuching under greenhouse condition
(Fig.2). The pepper cutting of cultivar (SemongokAman) was sown in pots filled with soil mixture containing peat: 
sand: soil: (1:1:1) mixture and maintained in greenhouse at $30 \pm 5^{0} \mathrm{C}$ throughout the experiments. The pepper cuttings with 7 new leaves stage were used for experiments in the greenhouse. The trial was laid out in completely randomized design (RCD) with the 5 treatment. (5) Five treatment of foliar application combination with NPK and fertilizer rate of soil NPK recommended by Malaysian Pepper Board were tested as follow:

Treatment 1: $0 \%$ of NPK + foliar fertilizer at concentration of $10 \mathrm{ml} / \mathrm{L}$ of water

Treatment 2: $25 \%$ of NPK + foliar fertilizer at concentration of $7.5 \mathrm{ml} / \mathrm{L}$ of water

Treatment 3: $50 \%$ of NPK + foliar fertilizer at concentration of $5 \mathrm{ml} / \mathrm{L}$ of water

Treatment 4: $75 \%$ of NPK + foliar fertilizer at concentration of $2.5 \mathrm{ml} / \mathrm{L}$ of water
Treatment 5: 100\% of NPK (Control)

Under Malaysian Pepper Board cultivation practice, the NPK compound fertilizer (N:12\%, P:12\%, K:17\%: Mg:2\%) was applied 6 time annually (every 2 month interval), following Malaysian pepper Board's recommendation rate. Watering was done 2 days interval to prevent transplanted cutting from wilting. A shade was constructed over the potted plants to prevent scorching by sun. The plants were allowed to growth for upto 12 months of age for taking observation on different growth parameter. Destructive sampling was done 1 year after the experiment to record the length of roots and total biomass. Nutrient status of leave at 12 months after planting was estimated using standard procedure [7]. The relative growth rate was determined by the following formulas [8].

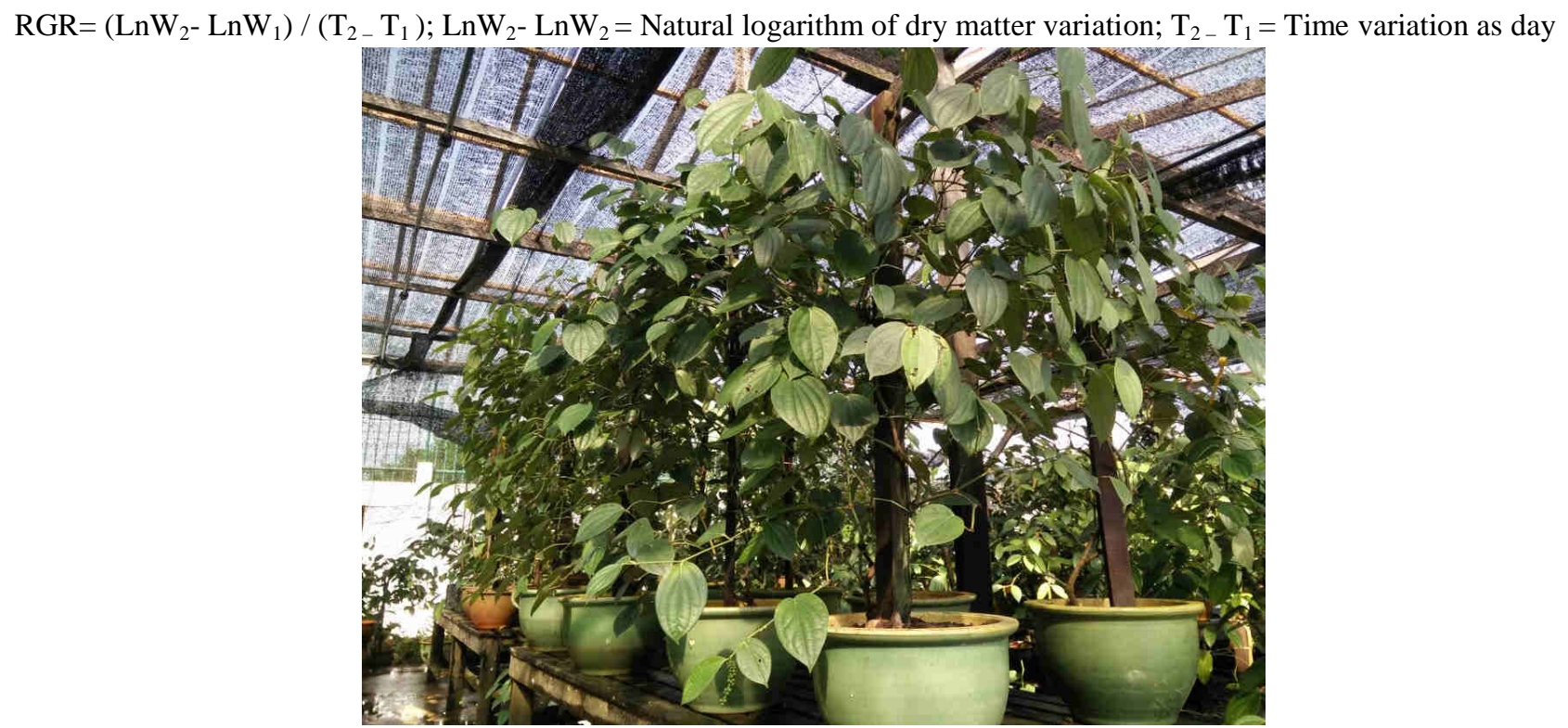

Fig.2: Potted trial used to test the effect of different fertilizer regime on vegetative growth under greenhouse condition

\section{RESULTS AND DISCUSSION}

\subsection{Nutrient uptake}

In pepper cultivation, poor nutrient management is the main problem faced by grower in Malaysia. Like other perennial crops, pepper also needs sufficient nutrient in addition to carbon dioxide and water to achieve an optimum growth and yield potential. Under normal condition, most of the nutrients are present in soil with limited quantity. With the hot and humid climate, most of the nutrient depleted especially in Sarawak with the annual rainfall ranged between $3500-4000 \mathrm{~mm}$. In order to enhance plant growth and increase production, the soil feeding is the most effective ways, but has limitations with its availability to pepper vines. For those elements with high water solubility e.g. potassium andnitrogen, most of these macronutrients are easily leached down to the soil and finally pollutes the groundwater. For instance nitrates can be harmful to humans. With increasing costs of fossil fuel, which provides the raw materials for fertilizer manufacture, there is a need to find innovations in fertilizer usage techniques. This problem is even more complex as pepper is a high nutrient demanding crop [1]. For this reason, efforts have been focused on reducing the rate of soil NPK fertilizer in order 
to sustain the pepper production and reducing environmental impact.

The effects of simultaneously application of soil NPK fertilizer with foliar fertilizer are presented in Table 2. The results reveal that the maximum nutrient uptake (N,P, K and $\mathrm{Mg}$ ) was brought out by decrease soil NPK fertilizer application to $50 \%$ with additional application of foliar fertilizer at concentration of $5 \mathrm{ml} / \mathrm{L}$ of water (Treatment 3) with the $\mathrm{N}$ uptake value of $21.33 \mathrm{mg}$; $\mathrm{P}, 1.95 \mathrm{mg}$; K 19.26 $\mathrm{mg}$ and $\mathrm{Mg}, 1.65 \mathrm{mg}$ respectively. This was followed by the application of soil NPK fertilizer application reduced to $75 \%$ with additional application of foliar fertilizer at concentration of $2.5 \mathrm{ml} / \mathrm{L}$ of water (Treatment 4). No significant different was observed among treatment 3 and 4 indicated that this fertilizer integration package was effective to stimulate the pepper growth to a maximum level. The solely application of soil NPK fertilizer although showed slightly less effective in nutrient uptake as compared to treatment 3 and treatment 4 , but this uptake was considered acceptable to achieved national pepper production target of $3.0 \mathrm{~kg} / \mathrm{vine}$. The application of foliar fertilizer only led to poor nutrient uptake.
Through this study, it was found out that reduced soil fertilization of NPK may be lead to improvement of balance with the other nutrient in the soil and prevent excessive leaching of nitrogen. The improvement of balance between soil nutrient, in addition to use of foliar application can increase cell permeability which make better penetration of NPK fertilizer $s$ into leaves and then to other organs which improved the root growth and its ability for nutrient uptake absorption and easily travel inside organs of plants and assimilation, this lead to improvement in nutrient uptake. This research finding is in conformity with research reported by Shaabanet al., 2009 [9] who reported that the nutrient uptake of wheat grown under surface irrigated system was at the optimal rate when foliar feeding was used in combination with soil fertilizer. Similar results were also observed by Allison and Jessica, 2015 [10] and mentioned the improvement of nutrient uptake in carrot was facilitated by sprayingof foliar fertilizer containing seaweed and hydrolyzed fish emulsion. The results obtained clearly indicated that this newly developed foliar fertilizer can be used on foliage to make more efficient utilization of nutrients.

Table.2: Uptake of nitrogen, phosphorus, potassium and magnesium by pepper vines upon 12 months after planting

\begin{tabular}{ccccc}
\hline Treatment & $\begin{array}{c}\text { N uptake } \\
(\mathrm{mg})\end{array}$ & $\begin{array}{c}\text { P uptake } \\
(\mathrm{mg})\end{array}$ & $\begin{array}{c}\text { K uptake } \\
(\mathrm{mg})\end{array}$ & $\begin{array}{c}\text { Mg uptake } \\
(\mathrm{mg})\end{array}$ \\
\hline Treatment 1 & $8.63^{\mathrm{d}}$ & $0.88^{\mathrm{c}}$ & $9.36^{\mathrm{d}}$ & $0.48^{\mathrm{d}}$ \\
Treatment 2 & $13.45^{\mathrm{b}}$ & $1.20^{\mathrm{b}}$ & $12.01^{\mathrm{c}}$ & $0.95^{\mathrm{c}}$ \\
Treatment 3 & $21.33^{\mathrm{a}}$ & $1.95^{\mathrm{a}}$ & $19.26^{\mathrm{a}}$ & $1.65^{\mathrm{a}}$ \\
Treatment 4 & $19.87^{\mathrm{a}}$ & $1.92^{\mathrm{a}}$ & $18.25^{\mathrm{a}}$ & $1.68^{\mathrm{a}}$ \\
Treatment 5 & $16.34^{\mathrm{b}}$ & $1.12^{\mathrm{b}}$ & $15.21^{\mathrm{b}}$ & $1.54^{\mathrm{b}}$ \\
\hline
\end{tabular}

Means in column with different letters are significantly different at 0.05 level using Duncan Multiple Range Test

\subsection{Growth parameter and it components}

The plant growth parameters of pepper cutting under different fertilizer regime are presented in Table 3. The results showed that the pepper vines response differently to the different fertilizer regime for manifestation of the growth characters. Among fertilizer regime, all the plant growth parameters were recorded to be the lowest in plants which received only the foliar fertilizer (Treatment 1). This finding is expected because of limited nutrient being supplied to the pepper vines. Although much of the research work reported that foliar feeding is the most dramatic and fast way of getting nutrients into plants with the efficacyof 5-20 times more effective than soil application [11, 12, 13], however, the main drawback on solely utilization of foliar fertilizer is the limited amounts of nutrients that can be applied at once as compared to soil fertilizer. This can be seen through the development of pale and yellowish leaves in the pepper vines (Fig.3). Concomitantly, it is evidence from the treatment 3 and 4 that that the application of foliar fertilizer in conjunction with soil fertilizer significantly increase the growth parameter of pepper cutting compared to solely application of soil NPK fertilizer (standard cultivation practice). This indicated that better nutrients supply received by treatment 3 and treatment 4 compared to other treatment regimes. In addition, the foliar fertilizer also contains various type of plant growth hormone such as auxin, cytokinin, salicylic acid and abscisic acid that are able to stimulate the vegetative growth of pepper cuttings. These results are in accordance with Anita and Leovegildo (2016) [13] on orchid and Kolota and Osinska, (2001) [14] on vegetable crops.In most of the studies, an increased 
amount of nutrient uptake led to an increase in the rate of assimilation and ultimately to better vegetative growth [15]. This finding was further confirmed by the highest plant dry weight and relative growth rate (RGR)in Treatment 3 with the weight and RGR value of $325.26 \mathrm{~g}$ and $4.59 \mathrm{gg}^{-1} \mathrm{day}^{-1}$ respectively. It is believed that pepper vine with better nutrient uptake and higher physiological activity would increase the photosynthesis process and thus stimulate the vegetative growth of pepper vines. From the analysis, the vegetative growth of pepper vine growth under treatment 3 regime was superior to treatment 4 although there were no significant differences treatments. This indicated that the nutrient applied might be the optimal fertilizer schedule for pepper vines. According to research finding reported bySadanandanet al., 2000 [16], pepper nutrient planted under treatment 3 and 4 was in sufficient range. For the treatment 2, even though the utilization of both foliar and soil NPK fertilizer has been report to sustain crop growth, but the growth parameter for pepper vine growth under this fertilizer package was significant lower than standard cultivation practice (Treatment 5). This could be due to the limited nutrient that soil NPK fertilizer could supply with additional of small quantity of foliar fertilizer input. This finding was further confirmed by Yap, 2012 [1]. He reported that pepper crop required approximately 62-10-62 $\mathrm{kg} \mathrm{ha}^{-1}$ of NPK annually in order to sustain the growth and soil nutrient balance. Of the parameter typically calculated, the most important is relative growth rate (RGR). Relative growth rate refers to the increase in plant mass per unit of mass present and per unit of time. The analysis of variance (ANOVA) on the relative growth rate indicated that the increase in plant mass differed significantly among different treatment except between treatment 3 and 4. These results prove that the utilization of foliar fertilizer in combination with soil NPK fertilizer could supply the plant with balance and sufficient nutrient that allow pepper vines to reach maximum growth rate. Besides, the vigorous growth of pepper vines can also be confirmed by the maximum nutrient uptake as shown in Table 1 . In term of pepper production, the dry weights of the black pepper berries per treatment were significantly different (Table 3 ). The yield of dried black pepper growth under treatment 3 and treatment 4 were higher than both those growth under solely application of soil NPK fertilizer and foliar fertilizer. This study also found out that integrated fertilizer regime growth under treatment 3 and 4 increase pepper yield by $11.74 \%$ and $13.88 \%$ respectively as compared to standard culture practice (Treatment 5) whereas under treatment 2 and treatment 1 regime, the pepper yield was decreased by $28.06 \%$ and $65.77 \%$ respectively. The differences in pepper yield between these treatment regimens were due principally to difference in nutrient supplied, the number of leaves and nutrient uptake by pepper among the five differences treatment.

Table.3: Effect of newly developed foliar fertilizer on black pepper plants

\begin{tabular}{ccccccccc}
\hline Treatment & $\begin{array}{c}\text { Height of } \\
\text { plants } \\
(\mathrm{cm})\end{array}$ & $\begin{array}{c}\text { Number of } \\
\text { node }\end{array}$ & $\begin{array}{c}\text { Number of } \\
\text { leaves per } \\
\text { plant }\end{array}$ & $\begin{array}{c}\text { Total root } \\
\text { length } \\
(\mathrm{cm})\end{array}$ & $\begin{array}{c}\text { Plant fresh } \\
\text { weight } \\
\left(\mathrm{g} \mathrm{p}^{-1}\right)\end{array}$ & $\begin{array}{c}\text { Plant dry } \\
\text { weight } \\
\left(\mathrm{g} \mathrm{p}^{-1}\right)\end{array}$ & $\begin{array}{c}\text { Black } \\
\text { pepper } \\
\text { yield } \\
\left(\mathrm{g} \mathrm{p}^{-1}\right)\end{array}$ & $\begin{array}{c}\text { RGR } \\
\left(\mathrm{gg}^{-1} \mathrm{day}^{-}\right. \\
1\end{array}$ \\
\hline Treatment 1 & $40.63^{\mathrm{c}}$ & $38.65^{\mathrm{c}}$ & $70.12^{\mathrm{d}}$ & $47.21^{\mathrm{d}}$ & $225.62^{\mathrm{d}}$ & $51.20^{\mathrm{d}}$ & $175.36^{\mathrm{d}}$ & $3.94^{\mathrm{d}}$ \\
Treatment 2 & $42.62^{\mathrm{c}}$ & $45.64^{\mathrm{b}}$ & $82.25^{\mathrm{c}}$ & $56.83^{\mathrm{c}}$ & $286.32^{\mathrm{c}}$ & $75.62^{\mathrm{c}}$ & $368.59^{\mathrm{c}}$ & $4.33^{\mathrm{c}}$ \\
Treatment 3 & $59.30^{\mathrm{a}}$ & $55.12^{\mathrm{a}}$ & $103.25^{\mathrm{a}}$ & $74.92^{\mathrm{a}}$ & $325.26^{\mathrm{a}}$ & $99.68^{\mathrm{a}}$ & $572.52^{\mathrm{a}}$ & $4.59^{\mathrm{a}}$ \\
Treatment 4 & $53.25^{\mathrm{a}}$ & $54.35^{\mathrm{a}}$ & $99.82^{\mathrm{a}}$ & $72.01^{\mathrm{a}}$ & $320.02^{\mathrm{a}}$ & $95.51^{\mathrm{a}}$ & $583.47^{\mathrm{a}}$ & $4.55^{\mathrm{a}}$ \\
Treatment 5 & $50.26^{\mathrm{b}}$ & $51.52^{\mathrm{ab}}$ & $90.56^{\mathrm{b}}$ & $67.42^{\mathrm{b}}$ & $307.56^{\mathrm{b}}$ & $88.65^{\mathrm{b}}$ & $512.36^{\mathrm{b}}$ & $4.49^{\mathrm{b}}$ \\
\hline
\end{tabular}

Means in column with different letters are significantly different at 0.05 level using Duncan Multiple Range Test 


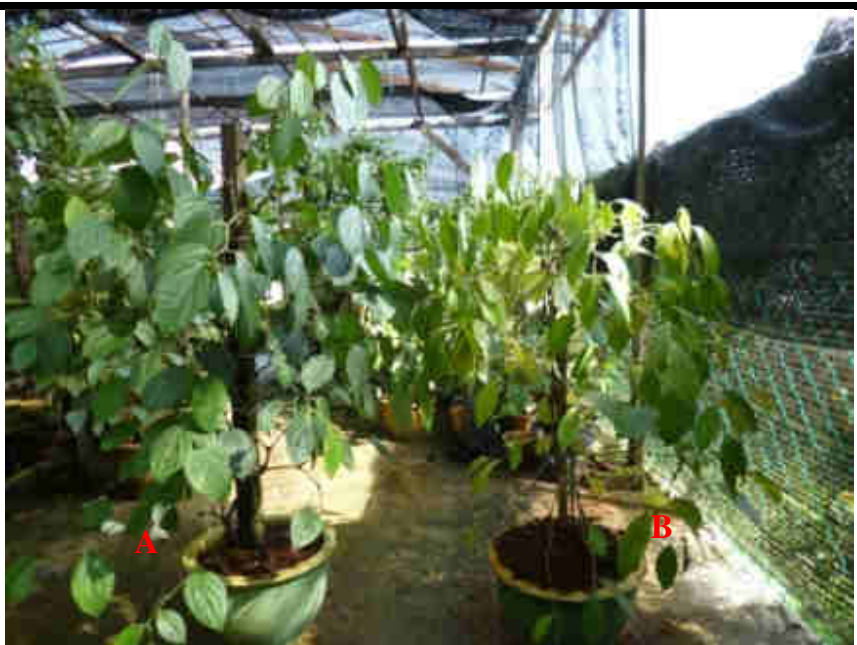

Fig. 3: Effect of different fertilizer treatment on plant physiology

A: plant showed vigorous growth when treated with $50 \%$ of NPK + foliar fertilizer at concentration of $5 \mathrm{ml} / \mathrm{L}$ of water

B: plant showed nutrient deficiency symptom when treated with foliar fertilizer only at concentration of $10 \mathrm{ml} / \mathrm{L}$ of water

\section{CONCLUSION}

This project was very meaningful in demonstrating the potential of newly developed foliar fertilizer as an option that provide positive effect on nutrient uptake which promoted the vegetative growth of black pepper. The application of foliar fertilizer is very efficient because the nutrient can be directly absorbed into the plant though leave and branches. Besides, this foliar fertilizer also contains various type of phytohormone that can stimulate the pepper growth. As indicated previously, the main reason for developing this foliar feeding is not to replace convention soil-applied fertilization. Due to the present of several undesirable process though the application of soil fertilizer e.g.nutirent leaching, runoff and being tied up in the soil in unavailable forms, the applications of foliar fertilizer is therefore designed to be an integral component of overall pepper vines nutrition programs. Further studies under field conditions should be conducted to verify the present finding in order to boost the growth and yield of black pepper plants.

\section{ACKNOWLEDGEMENT}

The authors wish to thank the Malaysian Pepper Board for financing and making the research possible. Lawrence akTuah, Sang ak Jam and Wan akAmbi are also thanked for excellent technical assistance.

\section{REFERENCES}

[1] C.A. Yap, "Determination of Nutrient Uptake Characteristic of Black Pepper (Piper nigrumL.)",
Journal of Agriculture Science and Technology, vol. 2 (18), pp. 1091-1099, 2012

[2] K.Kandiannan, "Growth regulators in black pepper production", Indiacocoa, arecanut and spices journal, vol. 18 (4), pp. 119-123, 1994

[3] C. K.Thankamani, K.Sreekala, M. Anandaraj, "Effect of Pseudomonas fluorescens (IISR-6) and Trichoderma harzianum (P-26) on growth ofblack pepper (Piper nigrum L.) in the nursery", Journal of Spices and Aromatic crops,vol. 14, pp.112-116, 2005

[4] B. Hamza, A.Suggars, "Biostimulants: myths and realities",Turfgrass Trends, vol. 10, pp. 6-10, 2001

[5] D. Kumar,"Salicylic acid signaling in disease resistance", Plant Sci, vol. 228, pp. 127-124, 2014

[6] P.Wójcik, "Uptake Of Mineral Nutrients From Foliar Fertilization", Journal of Fruit and Ornamental Plant Research, vol. 12, pp. 201-217, 2004

[7] C. A. Yap, "Impact of Different Fertilization Methods on the Soil, Yield and Growth Performance of Black Pepper (Piper nigrum L.)", Malaysian Journal of Soil Science, vol. 16, pp. 69-84, 2012a

[8] H.Farahani, G.Izzi, P.Steduto, T.Y. Oweis, "Parameterization and evaluation of AquaCrop for full and deficit irrigated cotton", Agronomy Journal, vol. 101, pp. 469-476, 2009

[9] S.H.A.Shaaban, F.M. Manal, M.H.M. Afifi, "Humic acid foliar fertilizer application to minimized soil applied fertilizer of surface irrigated wheat", World journal of Agriculture Sciences, vol. 5(2), pp. 207210, 2009 
[10] W. Allison, G. D. Jessica,"Effect Of Liquid Organic

Fertilizers And Seaweed Extract On

DaucusCarotaVar. SativusGrowth Characteristics", Proceeding of Western Nutrient Management

Conference. Reno, NV. Pp. 194-199, 2015

[11]C. Kaya, H.Kirnak, D.Higgs, "Enhancement of growth and normal growth parameters by foliar application of potassium and $\mathrm{P}$ in tomato cultivars grown at high $\mathrm{NaCl}$ salinity", Journal of Plant Nutrition, vol. 24, pp.353-367.2001

[12] K. Girma, K. L. Martin, K. W. Freeman, J.Mosali, R. K. Teal, W. R. Raun, S. M. Moges, D. B. Arnall, "Determination of optimum rate and growth for foliar applied phosphorus in corn", Communications in Soil Science and Plant Analysis, vol. 38, pp. 1137-1154, 2007

[13] D.M.Anita, B.M. Leovegildo, "Efficacy of bio input products as organic foliar orchids Fertilizer", International Journal of Applied Research, vol. 2(2), pp. 147-151, 2016

[14] E.Kolota, M.Osinska, "Efficiency of foliar nutrition of field vegetables grown at different nitrogen rates", Proc. IC Environ. Probl.N-Fert.ActaHort, vol. 563, pp. 87-91, 2001

[15] M. R. Mir, M.Mobin, N.A. Khan, M.A. Bhat, N.A. Lone, S.M.Razvi, S.A.Payne, "Crop responses to interaction between plant growth regulators and nutrient", Journal of phytology, vol. 2(10), pp. 09-19, 2010

[16] A. K.Sadanandan, "Agronomy and nutrition of black pepper”, In: Ravindran P N (Ed.), Black Pepper Piper nigrum, Harwood Academic Publishers, Amsterdam, pp. 163-223,2000 